\title{
Electrochemical Properties of Hybrid Supercapacitors Formed Based on Nanoporous Carbon and Nickel Tungstate
}

\author{
Yu.Yu. Starchuk ${ }^{1}$, B.I. Rachiy ${ }^{1}$, I.M. Budzulyak ${ }^{1}$, P.I. Kolkovskyi1, ${ }^{1, *}$ N.Ya. Ivanichok ${ }^{1}$, M.O. Halushchak ${ }^{2}$ \\ ${ }^{1}$ Vasyl Stefanyk Precarpathian National University, 57, Shevchenko St., 76018 Ivano-Frankivsk, Ukraine \\ ${ }^{2}$ National Technical University of Oil and Gas, Karpats'ka St., 76000 Ivano-Frankivsk, Ukraine
}

(Received 12 April 2021; revised manuscript received 05 December 2021; published online 20 December 2021)

\begin{abstract}
In this work, the morphology of carbon material (CM) has been researched by the nitrogen adsorption/ desorption method. Furthermore, it was determined that the specific surface area is about $1200-1300 \mathrm{~m}^{2} / \mathrm{g}$. $\mathrm{NiWO}_{4}$ was synthesized by co-precipitation method, and its structure was investigated by XRD. Additionally, the electrochemical properties of $\mathrm{CM}$ and $\mathrm{NiWO}_{4}$ were studied by the methods of chronoamperometry and voltammetry, and the use of these materials as electrodes of hybrid supercapacitors (HSC) - anode and cathode, respectively, was tested. A hybrid electrochemical system of the CM/KOH/NiWO ${ }_{4}$ type was formed. The use of this system makes it possible to increase the operating voltage range of HSC based on aqueous electrolytes from $0-1 \mathrm{~V}$ to $0.6-1.6 \mathrm{~V}$, and, consequently, to increase the energy characteristics of a unit cell by more than 2 times. It is shown that at operating currents of $1 \mathrm{~mA}$, the specific capacity of the $\mathrm{HSC}$ is $57.1 \mathrm{~F} / \mathrm{g}$, while the specific energy density and power are $7.09 \mathrm{Wh} / \mathrm{kg}$ and $1.39 \mathrm{~W} / \mathrm{kg}$, respectively.
\end{abstract}

Keywords: Electrochemical energy storage devices, Nickel tungstate, Porous carbon material, Aqueous electrolyte.

\section{INTRODUCTION}

One of the most common devices for the accumulation and storage of electrical energy is an electrochemical capacitor (EC), which is due to the fact that ECs have a high specific power, long cycle life and short charge/discharge time $[1,2]$.

The most common material for the production of EC electrodes is carbon material (CM) [3]. The advantages of $\mathrm{CMs}$ are low cost, ease of manufacture and versatility of existing forms (foam, powders, composites, monoliths, foils). CM-based ECs operate on the charge/discharge principle of an electric double layer (EDL). Therefore, for effective recharging of EDL, materials with a large specific surface area and pore size adapted to the size of ions are needed, which is decisive for the performance of ECs $[4,5]$. The porosity of CM and the pore size distribution were controlled depending on the chemical or physical activation performed. The most important parameters of the activation process are time, temperature and type of activating agent $[6,7]$.

Despite the large specific surface area of $\mathrm{CMs}$, the amount of charge accumulated in the EDL is not large enough, which in turn limits the specific capacity and energy density of the device. Therefore, one of the ways to increase the energy density of EC is the formation of hybrid ECs, in which positive and negative electrodes are made of materials with different mechanisms of accumulation of electric charge due to an expansion of the operating voltage range $[8,9]$. An increase in the voltage of a unit cell leads to a significant increase in the specific energy, and the use of CMs leads to an increase in the specific power of the device.

In this work, we study the effect of the porous structure of $\mathrm{CMs}$ on the electrochemical characteristics of HSCs formed based on CM and nickel tungstate.

\section{SYNTHESIS AND RESEARCH OF MATERIALS AND METHODS}

Nickel tungstate powdered material was obtained by co-precipitation method by mixing $\mathrm{Na}_{2} \mathrm{WO}_{4} \cdot 2 \mathrm{H}_{2} \mathrm{O}$ and $\mathrm{NiCl}_{2} \cdot 6 \mathrm{H}_{2} \mathrm{O}$. Thus, $\mathrm{NiCl}_{2} \cdot 6 \mathrm{H}_{2} \mathrm{O}(8 \mathrm{mmol})$ was dissolved in $50 \mathrm{ml}$ of distilled water and stirred at $70{ }^{\circ} \mathrm{C}$ for $10 \mathrm{~min}$ during the synthesis procedure. At the next stage, $40 \mathrm{ml}$ of $\mathrm{Na}_{2} \mathrm{WO}_{4} \cdot 2 \mathrm{H}_{2} \mathrm{O}(8 \mathrm{mmol})$ dissolved in distilled water was added dropwise. The addition process was carried out for $1 \mathrm{~h}$, then the resulting suspension was further stirred at $70^{\circ} \mathrm{C}$ for $3 \mathrm{~h}$. Finally, the light green precipitate was repeatedly washed with deionized water several times and dried at $80^{\circ} \mathrm{C}$ for $8 \mathrm{~h}$ in air.

CMs were derived from plant raw materials by carbonization and activation with potassium hydroxide. Moreover, dried apricot seeds as a feedstock were crushed to fractions from 0.25 to $1 \mathrm{~mm}$ and carbonized in a closed furnace at 330 to $350{ }^{\circ} \mathrm{C}$ with a heating rate of $10^{\circ} \mathrm{C} / \mathrm{min}$. Thus, the resulting carbon was mechanically crushed to fractions from 200 to $250 \mu \mathrm{m}$ and mixed with potassium hydroxide and water in a weight ratio: $m(\mathrm{C}): m(\mathrm{KOH}): m\left(\mathrm{H}_{2} \mathrm{O}\right)=1: 1: 2$. The resulting mixture was thoroughly stirred for 1 to $2 \mathrm{~h}$, after which it was dried in a thermostat to constant weight. Then, the dry material was placed in a furnace and heated in an argon atmosphere from 900 to $920^{\circ} \mathrm{C}$ at a heating rate of $10^{\circ} \mathrm{C} / \mathrm{min}$ and kept at this temperature for $20 \mathrm{~min}$. Finally, after cooling, the resulting material was washed with $5 \%$ aqueous $\mathrm{HCl}$ and distilled water to neutral $\mathrm{pH}$ and again dried at $90{ }^{\circ} \mathrm{C}$ to constant weight [10].

The characteristics of the porous structure (surface area and total pore volume) of CM were determined by analyzing sorption isotherms of nitrogen at its boiling point $(77 \mathrm{~K})$, obtained using a Quantachrome Autosorb Nova2200e (Quantachrome Instruments, Boynton Beach, FL, USA).

\footnotetext{
*pkolkovskyy@gmail.com
} 
Electrochemical investigation of the electrode material/electrolyte system was carried out in a threeelectrode cell. The working electrode was made of a mechanical mixture of the material under study and acetylene black in a ratio of $80: 20$. A platinum electrode was used as an auxiliary electrode, and a silver chloride $(\mathrm{Ag} / \mathrm{AgCl})$ reference electrode was placed in a $3.5 \mathrm{M}$ aqueous solution of $\mathrm{KCl}$ and combined with the working chamber through an agar-agar salt bridge. A $30 \%$ aqueous solution of $\mathrm{KOH}$ was used as the electrolyte. Electrochemical study was carried out using an Autolab PGSTAT/FRA-2 spectrometer in galvanostatic and potentiodynamic modes. Galvanostatic research was carried out at currents in a range of 1 to $100 \mathrm{~mA}$. The cyclic voltammetry (CVA) investigation was performed at a scan rate of 1 to $50 \mathrm{mV} / \mathrm{s}$. The specific capacitance of EC and hybrid supercapacitor (HSC) was calculated according to the procedure described in [11].

The performance characteristics of laboratory samples of HSC were determined in a two-electrode cell. In HSC, the cathode was made from a mechanical mixture of $\mathrm{NiWO}_{4}$ and acetylene black in a ratio of $80: 20$. Another electrode (anode) was made by mixing CM with acetylene black, also in a ratio of $80: 20$. Finally, the resulting electrode materials were pressed into a nickel mesh. Afterwards, the electrodes were leaked by the electrolyte, separated by a separator and placed in a two-electrode cell of $25 \times 25$ size. After that, they were sealed.

\section{RESULTS AND DISCUSSION}

The crystal structure of $\mathrm{NiWO}_{4}$ was investigated using X-ray diffraction analysis (CuKa radiation) in an angle range of $10^{\circ}<2 \theta<90^{\circ}$. The obtained material is amorphous and/or nanoscale in accordance with low intensity of diffraction peaks. Also, $\mathrm{NiWO}_{4}$ was kept in air at $600{ }^{\circ} \mathrm{C}$ for $1 \mathrm{~h}$. Nevertheless, diffraction peaks corresponding to nickel tungstate from the database of inorganic crystal structure (ICSD No. 15852) were established in the obtained X-ray diffraction pattern.

The morphology of the obtained CM was investigated by the method of low-temperature adsorption/ desorption of nitrogen, the quantitative characteristics of its porous structure are presented in Table 1.

Table 1 - Sorption properties of CM

\begin{tabular}{|c|c|c|c|}
\hline $\begin{array}{c}S_{B E T}, \\
\mathrm{~m}^{2} / \mathrm{g}\end{array}$ & $\begin{array}{c}S_{L}, \\
\mathrm{~m}^{2} / \mathrm{g}\end{array}$ & $\begin{array}{c}S_{D F T}, \\
\mathrm{~m}^{2} / \mathrm{g}\end{array}$ & $\begin{array}{c}S_{\text {t-micro }}, \\
\mathrm{m}^{2} / \mathrm{g}\end{array}$ \\
\hline 1236 & 1405 & 1085 & 1040 \\
\hline $\begin{array}{c}S_{\text {BJH-meso }}, \\
\mathrm{m}^{2} / \mathrm{g}\end{array}$ & $\begin{array}{c}S_{\text {micro }}, \\
\%\end{array}$ & $\begin{array}{c}V_{\text {total }}, \\
\mathrm{cm}^{3} / \mathrm{g}\end{array}$ & $\begin{array}{c}V_{\text {micro }}, \\
\mathrm{cm}^{3} / \mathrm{g}\end{array}$ \\
\hline 160 & 84 & 0.69 & 0.41 \\
\hline
\end{tabular}

In particular, the specific surface area was determined by the BET $\left(S_{B E T}\right)$ method with a linear dependence of $1 /\left[W\left(p_{0} / p\right)^{-1}\right]$ on $p_{0} / p$ in the adsorption isotherm range for the $p_{0} / p$ ratio in the range from 0.05 to 0.35 [12]. In addition, Langmuir $\left(S_{L}\right)$ and DFT $\left(S_{D F T}\right)$ methods were used to determine the total surface area of microporous CMs. The area of micropores was determined by the $t$-method $\left(S_{t \text {-micro }}\right)$, and mesopores - by the BJH method $\left(S_{B J H-m e s o}\right)$. The total pore volume $\left(V_{\text {total }}\right)$ was calculated from the amount of adsorbed nitrogen at $P / P_{0} \sim 1.0$, the volume of micropores $\left(V_{\text {micro }}\right)$ was determined using the $t$-method. In the obtained CM, the specific area of mesopores is up to $15 \%$ of the total surface area, which is $1200-1300 \mathrm{~m}^{2} / \mathrm{g}$. It is determined by the above three methods and correlates within an error of $10 \%$. The micropore volume determined by the $t$-method is $0.41 \mathrm{~cm}^{3} / \mathrm{g}$, which is about $60 \%$ of the total pore volume determined at maximum pressure. Mesopores play the role of transport channels for adsorbate or electrolyte to enter micropores.
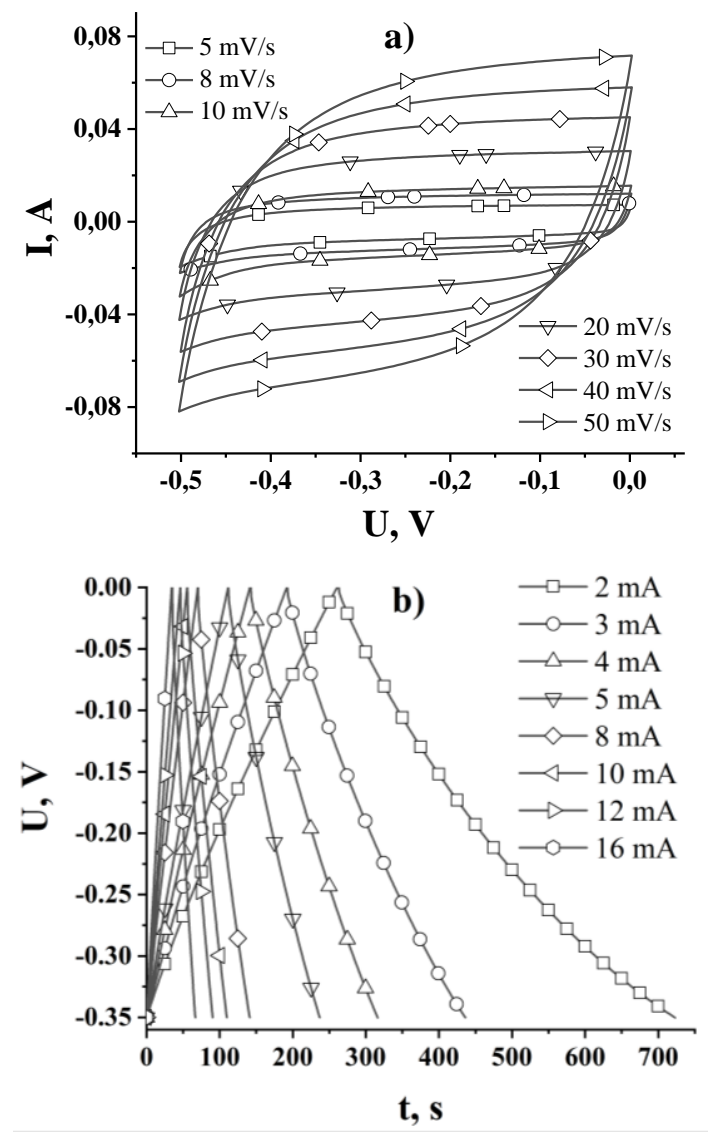

Fig. 1 - CVA curves (a) and galvanostatic charge-discharge curves (b) of the CM

Electrochemical studies of the obtained CM were carried out using a three-electrode cell. Cyclic voltammograms of the material under research are typical for EC with EDL (Fig. 1a). On the one hand, with increasing scan rate, the CVA curves deviate from a rectangular shape due to an increase in the internal resistance of the electrochemical system. On the other hand, with increasing scan rate, small diameter pores are available for electrolyte ions, they cause internal resistance, which is the result of diffusion, which restricts the movement of electrolyte ions in these pores [13].

The value of the specific capacity of the carbon electrode was determined from area $A$ of the CVA curves by integrating the cathodic current $I(U)$ to the potential $U$, in the range from the anode limiting voltage $U_{a}$ to the cathode limiting voltage $U_{c}$ and dividing by the scan rate $s$, mass of the nanocomposite and voltage rate $\left(U_{a}-U_{k}\right)$ by the formula: $C=A /\left(2 m s\left(U_{a}-U_{k}\right)\right)$. At a scan rate of $5 \mathrm{mV} / \mathrm{s}$, the specific capacity is $110 \mathrm{~F} / \mathrm{g}$ and decreases to $79 \mathrm{~F} / \mathrm{g}$ at a scan rate of $50 \mathrm{mV} / \mathrm{s}$. 
Fig. 1b shows the charge/discharge curves obtained for the carbon electrode. The investigated CM is electrochemically stable in this electrolyte, as evidenced by the linear dependence of the voltage on the discharge current, varying within 2-16 mA. Moreover, based on the obtained discharge curves, the specific capacities of the CM were determined. At a discharge current of $2 \mathrm{~mA}$, the specific capacity is $212 \mathrm{~F} / \mathrm{g}$.
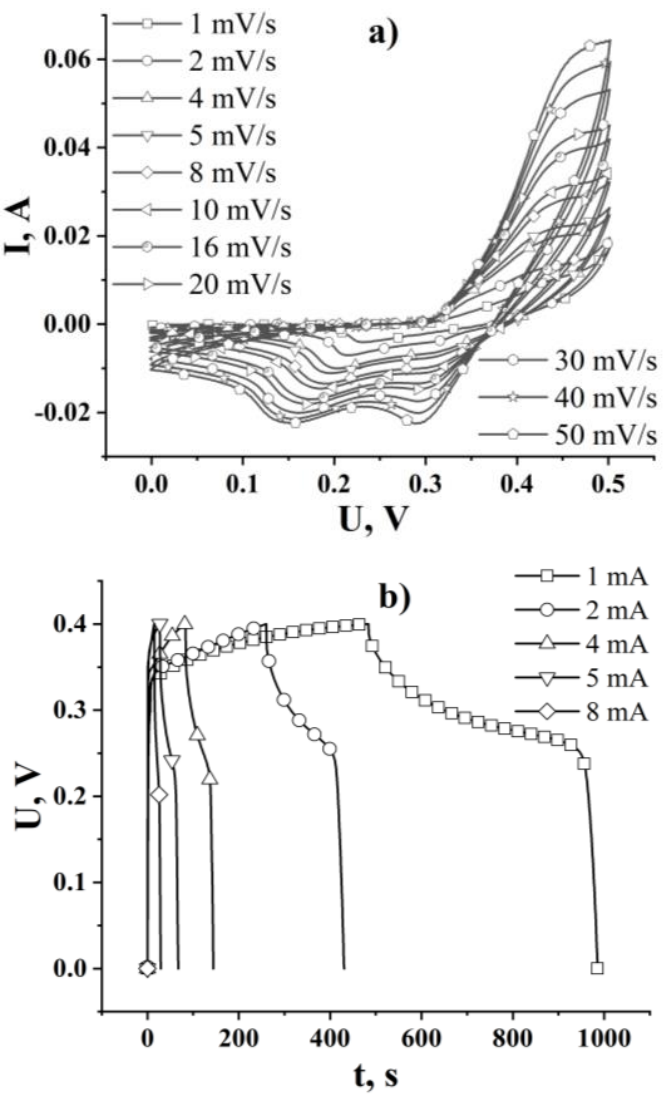

Fig. 2 - CVA curves (a) and galvanostatic charge-discharge curves (b) of the $\mathrm{NiWO}_{4} /$ electrolyte system

The CVA curves of the nickel tungstate/electrolyte electrochemical system are shown in Fig. 2a. All CVA curves have redox peaks, one anodic and cathodic peaks $(U=0.23 \mathrm{~V})$ at low scan rates $(1-5 \mathrm{mV} / \mathrm{s})$, which shift towards a lower potential $(U=0.15 \mathrm{~V})$ at a scan rate of $50 \mathrm{mV} / \mathrm{s}$, and with an increase in the scan rate $(s>10 \mathrm{mV})$, a second cathode peak begins to appear $(U=0.3 \mathrm{~V})$. The presence of peaks indicates the passage of electrochemical reactions, due to which the charge is accumulated. An increase in the scan rate by an order of magnitude (from 1 to $10 \mathrm{mV} / \mathrm{s}$ ) leads to a twofold decrease in the specific capacity of the system, which indicates the prospect of using these materials at low scan rates.

Fig. 2b illustrates the discharge curves for the $\mathrm{NiWO}_{4} /$ electrolyte system obtained by the galvanostatic method. A linear section is observed in the voltage range $0.2-0 \mathrm{~V}$, which is related to the capacity of the EDL formed at the electrode/electrolyte interface, and a plateau in the range $0.25-0.35 \mathrm{~V}$, which is associated with pseudo-minus charge storage. Based on the experimentally obtained discharge curves (Fig. 2b), the dependence of the specific capacity of the system on the value of the discharge current was calculated. The specific capacity value at a discharge current of $1 \mathrm{~mA}$ is $105 \mathrm{~F} / \mathrm{g}$ and gradually decreases with an increase in the discharge current.

Therefore, based on research of the electrochemical behavior of a $\mathrm{CM}$ in the negative potential range and nickel tungstate in the positive one, a hybrid electrochemical system of the $\mathrm{CM} / \mathrm{KOH} / \mathrm{NiWO}_{4}$ type was formed. The use of materials with different nature of charge accumulation in an electrochemical system allows it to operate at higher voltages and, accordingly, increases the energy characteristics of a unit cell. The study of the joint functioning of electrode materials in a hybrid electrochemical system was carried out by the potentiodynamic method. To determine the optimal operating voltage of a single element, potentiodynamic investigations were carried out in a voltage range of $0-1.6 \mathrm{~V}$. The operating potential window was 1 V. Fig. 3 illustrates the CVA curves obtained for HSC of the $\mathrm{CM} / \mathrm{KOH} / \mathrm{NiWO}_{4}$ type at various operating potentials and a scan rate of $1 \mathrm{mV} / \mathrm{s}$. In the entire voltage range, the operation of the electrochemical system is stable.

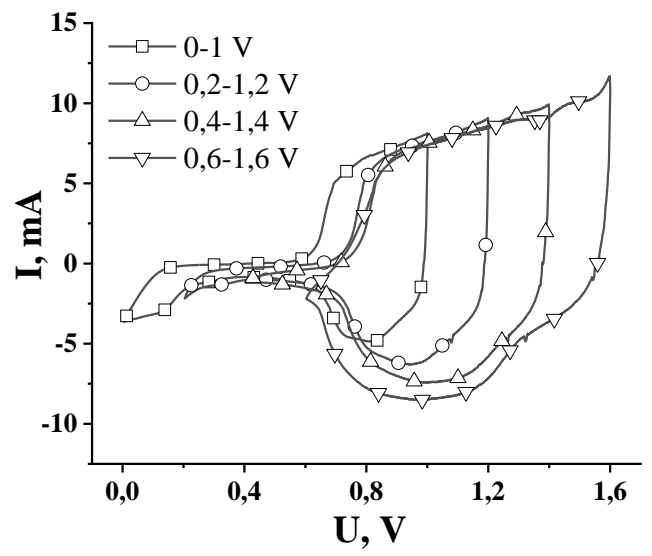

Fig. 3 - CVA curves for HSC at different working potentials

Based on the experimentally obtained CVA curves (Fig. 3), the values of the specific capacity of HSC were determined, which are $27.3,32.9,47.1$, and $62.4 \mathrm{~F} / \mathrm{g}$ in accordance with the values of the working potential 0 $1,0.2-1.2,0.4-1.4$, and 0.6-1.6 V. The HSC showed stability in the voltage range $0.6-1.6 \mathrm{~V}$; therefore, further electrochemical research was carried out in that potential range.

Fig. 4 shows the dependence of the specific capacity on the scan rate for the $\mathrm{CM} / \mathrm{KOH} / \mathrm{NiWO}_{4}$ system. It can be seen that the specific characteristics of the device decrease. In addition, depending on the scan rate, the redox reactions responsible for the amount of charge accumulation must be fast and vice versa, otherwise the charge accumulation decreases sharply.

The dependence of the specific capacity on the scan rate was calculated based on the obtained potentiodynamic curves for CM (Fig. 1a) and $\mathrm{NiWO}_{4}$ (Fig. 2a). For $\mathrm{CM}$ at a scan rate of $5 \mathrm{mV} / \mathrm{s}$, the capacity is $110 \mathrm{~F} / \mathrm{g}$ and decreases linearly to $79 \mathrm{~F} / \mathrm{g}$ with increasing scan rate to $50 \mathrm{mV} / \mathrm{s}$. For $\mathrm{NiWO}_{4}$ at a scan rate of $1 \mathrm{mV} / \mathrm{s}$, the capacity is $98 \mathrm{~F} / \mathrm{g}$ and decreases faster than for CM to $15 \mathrm{~F} / \mathrm{g}$ at $50 \mathrm{mV} / \mathrm{s}$, which is associated with the low rate of adsorption/desorption of ions. 

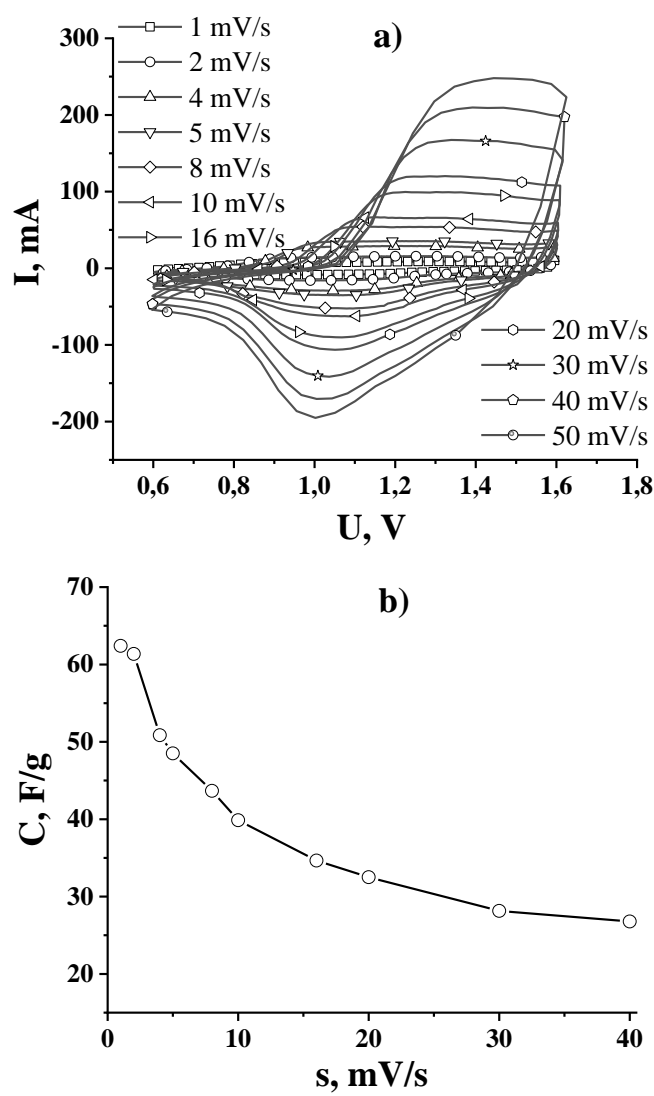

Fig. 4 - CVA curves of the $\mathrm{CM} / \mathrm{KOH} / \mathrm{NiWO}_{4}$ system at a scan rate of $1-50 \mathrm{mV} / \mathrm{s}(\mathrm{a})$, dependence of the specific capacity on the scan rate (b)

The value of the specific capacity was calculated at various charge-discharge currents based on the chargedischarge curves for $\mathrm{CM}$ (Fig. 1b) and $\mathrm{NiWO}_{4}$. It was determined that for $\mathrm{CM}$ with a discharge current of $2 \mathrm{~mA}$, the capacity is $212 \mathrm{~F} / \mathrm{g}$, while for $\mathrm{NiWO}_{4}$, the capacity is $104 \mathrm{~F} / \mathrm{g}$ at a discharge current of $1 \mathrm{~mA}$. It was determined that the capacity in this case for $\mathrm{NiWO}_{4}$ decreases much faster than for CM based on the calculated capacity from the charge-discharge curves for $\mathrm{NiWO}_{4}$ and CM.

HSC differs from classical EC by the presence of an unpolarized electrode, in this case of $\mathrm{NiWO}_{4}$, on which Faraday reactions can be seen. Although the capacitance for potentiodynamic or galvanostatic curves drops faster for $\mathrm{NiWO}_{4}$ than for $\mathrm{CM}$ with increasing scan rate or discharge current, using an unpolarized electrode in the HSC we managed to raise the operating voltage to $1.6 \mathrm{~V}$. The capacity of this $\mathrm{HSC}$ is $62.4 \mathrm{~F} / \mathrm{g}$ at a scan rate of $1 \mathrm{mV} / \mathrm{s}$ and reaches $26.8 \mathrm{~F} / \mathrm{g}$ at a scan rate of $40 \mathrm{mV} / \mathrm{s}$. In this case, the specific energy and specific power are $7.09 \mathrm{~W} \cdot \mathrm{h} / \mathrm{kg}$ and $1.39 \mathrm{~W} / \mathrm{kg}$, respectively.

The pseudocapacitive behavior of HSC is additionally confirmed by galvanostatic curves (Fig. 5) of a nonlinear nature. The voltage plateaus formed are in good agreement with peaks observed on the corresponding CVA. The specific capacity for $\mathrm{CM} / \mathrm{KOH} / \mathrm{NiWO}_{4} \mathrm{HSC}$ is $57.1 \mathrm{~F} / \mathrm{g}$, which corresponds to a discharge current of $1 \mathrm{~mA}$. These values are higher than the value for a symmetric supercapacitor under the same conditions.

Therefore, based on the data obtained from Fig. 4b, the total capacity of materials can be divided into EDL capacity $(C E D L)$ and diffusion-controlled redox capacity due to fast Faraday reverse reactions $\left(C_{F}\right)$ [14]. In the kinetic model [15], it is assumed that the scan rate affects the total specific electrochemical capacity of the system, since the diffuse component of the capacitance $\left(C_{V}\right)$ is a function of the reaction time. As a result, the scan rate can be considered inverse to the diffusion time. Thus, in the case of semi-infinite linear diffusion, the total capacity is related to the scan rate by the following equation: $C=C_{s=\infty}+a / s^{-1}$, where $a$ is a constant value and $C_{E D L}=C_{s=\infty}$.

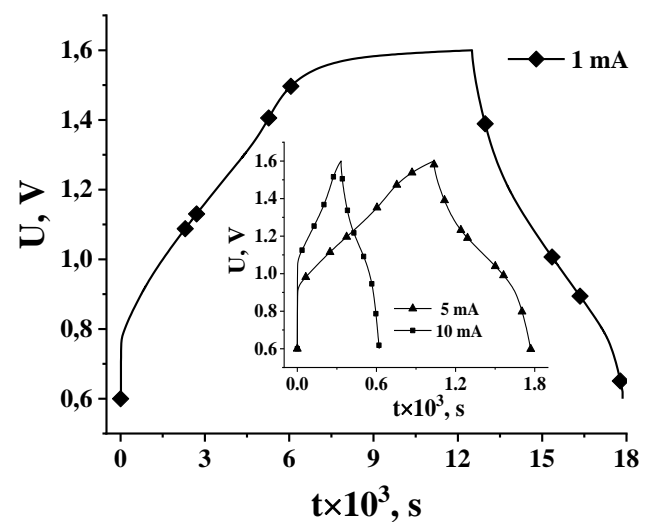

Fig. 5 - Galvanostatic curves for $\mathrm{CM} / \mathrm{KOH} / \mathrm{NiWO}_{4} \mathrm{HSC}$ at charge/discharge currents of 1,5 and $10 \mathrm{~mA}$

Table 2 - Specific capacitive characteristics of the $\mathrm{CM} / \mathrm{KOH} /$ $\mathrm{NiWO}_{4}$ system

\begin{tabular}{|c|c|}
\hline Capacitor type & $\mathrm{CM} / \mathrm{NiWO}_{4}$ \\
\hline$C_{E D L}, \mathrm{~F} / \mathrm{g}$ & 32.8 \\
\hline$C_{\max }, \mathrm{F} / \mathrm{g}$ & 90.9 \\
\hline
\end{tabular}

Extrapolation of the dependences of $C$ on $s^{-1 / 2}$ to the $Y$-axis made it possible to determine the specific capacity of the EDL of the materials under research (Table 2). A decrease in the scan rate leads to an increase in the specific capacity. Thus, the dependence of the specific capacity on the scan rate can be extrapolated in the other direction to $s=0$, using the functional dependence on $s$ [14]. Since $C$ increases linearly with $s^{1 / 2}$, then $1 / C$ should decrease linearly with $s^{1 / 2}$. Then, $1 / C=1 / C_{s=\infty}+b s^{-1}$, where $C_{s=\infty}$ is the maximum specific capacity that can be obtained, and $b$ is a constant. The inverse value of the specific capacity linearly depends on $s^{1 / 2}$. Extrapolation of the dependences of $C^{-1}$ on $s^{1 / 2}$ to the $Y$-axis allowed us to determine the maximum specific capacity of the studied materials (Table 2).

\section{CONCLUSIONS}

It was found that in HSCs based on $\mathrm{CM}$ and $\mathrm{NiWO}_{4}$ it is possible to increase the operating voltage to the limits of $0.6-1.6 \mathrm{~V}$, which provides their high specific capacity, in particular, at a discharge current of $1 \mathrm{~mA}$. Moreover, it was determined that the specific capacity is $57.1 \mathrm{~F} / \mathrm{g}$, and the specific energy density and power are $7.09 \mathrm{~W} \cdot \mathrm{h} / \mathrm{kg}$ and $1.39 \mathrm{~W} / \mathrm{kg}$, respectively.

\section{ACKNOWLEDGEMENTS}

This work was supported by the National Research Foundation of Ukraine (project 2020.02/0043). 


\section{REFERENCES}

1. B.E. Conway, Electrochemical Supercapacitors - Scientific Fundamentals and Technological Applications (Kluwer Academic/Plenum: New York: 1999).

2. C. Largeot, C. Portet, J. Chmiola, P. Taberna, Y. Gogotsi, P. Simon, J. Am. Chem. Soc. 130, 2730 (2008).

3. R.Y. Shvets, I.I. Grygorchak, A.K. Borysyuk, S.G. Shvach-ko, A.I. Kondyr, V.I. Baluk, A.S. Kurepa, B.I. Rachiy, Phys. Solid State 56 No 10, 2021 (2014).

4. S. Kandalkar, D. Dhawale, C. Kim, C. Lokhande, Synth. Met. 160, 1299 (2010).

5. E. Frackowiak, F. Beguin, Carbon 39, 937 (2001).

6. M. Inagaki, New Carbons; Control of Structure and Functions (Elsevier: Amsterdam: 2000).

7. R.C. Bansal, J. Donnet, F. Stoeckli, Active Carbon (Marcel Dekker: New York: 1988).

8. V. Khomenko, E. Raymundo-Piñero, E. Frackowiak, F. Beguin, Appl. Phys. A 82, 567 (2005).

9. J.P. Zheng, J. Electrochem. Soc. 150, A484 (2003).

10. B.K. Ostafiychuk, I.M. Budzulyak, M.M. Kuzyshyn, B.I. Rachiy, R.A. Zatorskiy, R.P. Lisovskiy, V.I. Mandzyuk, J. NanoElectron. Phys. 5 No 3, 03049 (2013).

11. B.I. Rachiy, I.M. Budzulyak, E.A. Ivanenko, S.L. Revo, Surf. Eng. Appl. Electrochem. 51 No 5, 501 (2015).

12. A.P. Karnaukhov, Novosibirsk: Science. Sib. enterprise of the Russian Academy of Sciences, 470 (1999)

13. B.I. Rachiy, Yu.Yu. Starchuk, P.I. Kolkovskyy, I.M. Bud-zulyak, L.S. Yablon, V.O. Kotsyubynsky, O.V. Morushko, O.M. Khemiy, Surf. Eng. Appl. Electrochem. 56 No 6, 697 (2015).

14. H. Wang, L. Pilon, Electrochimica Acta 64, 130 (2012).

15. S. Ardizzone, G. Fregonara, S. Trasatti, Electrochimica Acta 35, 263 (1990).

\section{Електрохімічні властивості гібридних суперконденсаторів, сформованих на основі нанопористого вуглецю та вольфрамату нікелю}

\section{Ю.Ю. Старчук ${ }^{1}$, Б.І. Рачійํㄹ І.М. Будзуляк ${ }^{1}$, П.І. Колковський ${ }^{1}$, Н.Я. Іванічок ${ }^{1}$, М.О. Галущак ${ }^{2}$}

${ }^{1}$ Прикарпатський національний університет імені Василя Стефаника, вул. Шевченка, 57, 76018 Івано-Франківськ, Украӥна

${ }^{2}$ Національний технічний університет нафьти і газу, вул. Карпатська, 15, 76000 Івано-Франківськ, Україна

В роботі проведено дослідження морфології поверхні вуглецевого матеріалу (ВМ) методом адсорбції/десорбції азоту та визначено питому площі поверхні, яка становить 1200-1300 м²/г. Методом співосадження синтезовано $\mathrm{NiWO}_{4}$ та досліджено його структуру. Досліджено електрохімічні властивості $\mathrm{BM}$ та $\mathrm{NiWO}_{4}$ методами хроноамперометрії та вольтамперометрії, а також апробовано використання даних матеріалів як електродів гібридних суперконденсаторів (ГК) - анода та катода відповідно. Сформовано гібридну електрохімічну систему типу $\mathrm{BM} / \mathrm{KOH} / \mathrm{NiWO}_{4}$. Використання такої системи дозволяе підвищити робочий діапазон напруги ГК на основі водних електролітів з 0-1 В до 0,6-1,6 B, а отже, і підвищити енергетичні характеристики одиничної комірки більше, ніж у 2 рази. Показано, що при робочих струмах 1 мА питома емність ГК становить 57,1 Ф/г, при цьому питома густина енергії та потужність становлять 7,09 Вт·год/кг та 1,39 Вт/кг відповідно.

Ключові слова: Електрохімічні накопичувачі енергії, Вольфрамат нікелю, Пористий вуглецевий матеріал, Водний електроліт. 